\title{
A Touchable Woman's Untouchable Daughter: Interplay of Caste and Gender in Nepal
}

\author{
Sarita Pariyar'
}

\begin{abstract}
Drawing on more than a decade of multidisciplinary engagement with politics of dignity and social justice, this essay critically interrogates the influence of Hindu jurisprudence and its connections to the current Nepali constitution on the lower or 'impure' castes, especially women. The author argues that, notwithstanding the abolition of the caste system more than 50 years ago, the new constitution, which defines secularism as Sanatan Dharma-essentially preserving old Hindu traditions and practices under the law-continues to perpetuate discrimination against Dalits and other marginalized groups. She cites her own experience as an 'untouchable' child of a mixed-caste marriage and the tragic experience of an inter-caste alliance that led to the death of the 'lower caste' groom to examine our understanding of and prospects for love, violence, social inclusion/exclusion, family, citizenship, and society in Nepal. The essay succinctly focuses on the intersectionality of caste, class, gender, and religion that continues to shape everyday life and future of the ordinary people in the predominantly Hindu country.
\end{abstract}

\section{Keywords}

Intersectionality, Hinduism, caste, class, gender, inter-caste marriage.

\section{Introduction}

I am an 'untouchable' woman born from a 'touchable' womb. My mother was a Kshatriya, a 'high-caste touchable' woman. My father was from the Damai tailor caste, an 'untouchable'. Because my mother married my father, she lost her caste status; she was labeled 'impure' for the rest of her life.

The history of my family, my society, and my nation-I always carry it with me. This sentiment expressed by James Baldwin in The Price of the Ticket: Collected Nonfiction, 1948-1985, resonates more and more as I examine my own life. 
My mother's name was Binu Thapa. She was 5 feet 8 inches tall, thin, had a fair complexion with sunken eyes. She applied mustard oil in her hair to braid it without a rubber band. She was a hard working, determined person, who would not shy away from doing any kind of work. She used to run a small iron workshop in Hetauda, a small Nepali city in the Terai region where the Indo-Gangetic plains meet the Himalayan Range. She used to return to our village home late at night sitting in the rear of a truck, with toddlers in one hand and food in the other. Fetching water in the dark from the Rapti river was not a problem; compulsions made her fearless. She could never have imagined that her marriage to an 'untouchable' person would so drastically change her life and that she would give birth to seven 'untouchable' children.

My mother's parents were modest farmers. Buwa, my father, was the neighborhood tailor. He had a wheatish complexion and sharp eyes, spoke more than six languages, and liked to work. He was fond of singing too.

I was a normal child, like any other kid - How would I have known the meaning of being touchable or untouchable? But people reminded me every day that I was different.

Basamadi village, where my parents lived, is seven kilometers west of Hetauda. It sits below beautiful green hills, near the Rapti river. Basamadi is named after a nearby Shiva temple, Basaha Mahadeva. We lived right on Nepal's major East-West Highway, named for one of Nepal's recent monarchs, King Mahendra. The highway was like our front yard. I grew up in a concrete house with electricity.

One day, nearly twenty years ago, when I was twelve, I went to the village shop to buy bread. When I got home, my father saw the bread was stale. 'Return the bread,' he told me. The high-caste shopkeeper refused to take the bread back because I had touched the package. When I told my father, he was angry. 'Go, return it,' he ordered. 'If he won't take it, throw it in his face. I'll take care of whatever comes after that.'

I was frightened. Neither did I have the courage to throw the bread at the shopkeeper nor could I defy my father. I sat by the road for a long time, scared. I wondered why I hadn't been given the right goods even though I had paid for them. The bread hadn't turned stale from my touch - and I had paid full price for a fresh loaf. I gathered all of my courage and confronted the shopkeeper. 'Please return my money, and please take your bread back.'

'What a stubborn girl!' he muttered as he returned the money. I clutched the paper bills in my sweaty hands and rushed home. I began to ask myself: Why had the shopkeeper refused to take the bread back? If the bread had become impure because of me, did it mean that my body was dirty or impure?

When I was about eight years old, I realized that people came in two groups touchable or pure, and untouchable or impure. Even as a child, whenever I was told that I shouldn't touch someone or something because I would pollute them, it made me ask - What am I? The rules seemed so arbitrary. Who and what could I not touch, where, and when? Who could be touched and who not? I wanted to be a touchable person, just like everybody else. But there is no freedom to transform into a touchable person if you're born an untouchable.

Later, another curiosity arose: What is caste? Why is one group ranked above another from birth? I never stopped thinking about my originally touchable mother, who gave birth to untouchable children, and the history tied to it. In her work, Uma Chakravarti examines Brahminical patriarchy as a unique structure of the Hindu caste order, in which caste and gender are interlinked and reinforce each other. Through 
continuation of brahmanical patriarchy, sexual control over upper caste women is not only to subordinate them but also to maintain caste purity (Chakravarti, 2003, p. 34).

My mother is a victim of that system. Because she fell in love with an 'untouchable' man, she was forced to abandon her family and friends, the village of her birth, and her lineage. My mother's family couldn't visit her, nor could she see them. My mother was treated like a dead cow. One day, my mother's sister wanted to visit but her family forbade it. It seemed everyone in my mother's family stopped loving her. Caste hatred grew in their bellies; they also feared that their relatives and neighbors would shun them.

Five years ago, twenty-six years after my mother's passing, I met my mother's brother and uncle - my uncle and great-uncle - for the first time. It was at an event to mourn the loss of a relative.

My uncle repeatedly told me to lie about my full name when meeting my great uncle. If he knew my caste, he might not accept me. But I told my great uncle my full name, loudly and clearly. He was in his eighties and went on sharing his old memories like live radio. It was delightful listening to him. He did not care about my caste. My uncle was surprised, but even afterwards kept warning me with his eyes and gestures. 'Sorry niece!' he said. 'Although it has been a long time, I still cannot take you to the village home where your mother grew up. Your aunty is very traditional. She would not let you into the house if she knew you were a Dalit.' He wanted to keep the family skeletons in the closet.

Seeing this long history of social boycott of my mother and untouchables made me more determined to learn and fight for dignity. That became the passion of my life. After marrying my mother in the 1960s, fortunately, my father wasn't killed. Back then, so-called 'untouchable' people were sometimes killed for falling in love with socalled 'touchable' persons. It still happens today. On July 14, 2016, Ajit Mijar Dhakal, a Dalit boy, was found dead at Kumpur-3 in Dhading District. The Asian Human Rights Commission (AHRC) claims that Ajit did not die because of suicide; rather, it was a staged murder. Ajit's neck was loosely tied by a tent rope and his legs touched the floor. He had been threatened with murder within the past 72 hours. Police quickly buried his body without publicizing about the unclaimed corpse and they harassed his family when they demanded for the body.

Ajit married Kalpana Parajuli, a Brahmin girl. Although Ajit's grandfather was a Brahmin, he had married an 'untouchable', so Ajit's father had become an 'untouchable', as did Ajit. He was 18 and Kalpana was 17. Despite Kalpana's family dis-agreement, they got married. They were both residents of Panchkhal in Kavre District.

It has been over four years, but the body of that young lover still hasn't received its funerary rites. His family won't let that happen; they believe the district court denied them justice. Ajit's corpse is lying on a slab of ice in a hospital morgue in Kathmandu, still awaiting justice (Pariyar, 2018).

In Nepal, many have been killed for falling in love with high caste women, and many Brahmin men have lost their caste status for marrying 'untouchable' women. According to historians Tulasi Ram Vaidya and Tri Ratna Manandhar, in ancient Nepal 'If a Shudra (low caste) had physical relations with a Dwija woman (high caste), there were laws that called for the man's body to be mutilated, his property, everything to be confiscated; even life.' Punishments were given on the basis of caste (Vaidya and Manandhar, 1985, p. 47). 
During the Rana period (1846-1951), the Nepali king appointed a Brahmin as the dharmadhikari (pontiff) to decide on religious matters such as restriction of food and water, and cases of sexual relations between the lower caste and other caste groups (Regmi, 2002, p. 61; Pariyar 2018).

What the dharmadhikaris did in the past, judges and lawyers are doing today. The lawyer for Ajit's killers reportedly told the court, 'Your Honour - what else would be the outcome if the son of (an untouchable) cobbler elopes with the daughter of a Brahmin?'

Ancient Hindu texts contain many examples of caste status of people being raised or lowered to justify retribution in case of inter-caste alliances. Provisions for 'lowering' caste status are listed in the Manusmriti, the ancient Hindu legal text codified over two thousand years ago. In fourteenth century Nepal, during the reign of King Jaya Sthiti Malla, jurisprudence was codified as Manav Nyayashashtra. It describes the conditions and circumstances for conferring lower caste-status on people. The caste system was further entrenched in society with the adoption of the legal code Muluki-ain in 1854 under the Ranas. For over a hundred years (1854-1963), the Muluki-ain of 1854 formally divided the Nepali society into the touchable (pure) and the untouchable (impure) ${ }^{1}-$ those whose touch necessitated purifying rituals and those whose touch didn't; those who could be enslaved and those who couldn't. The government even had different penalties for the same crime, depending on caste (Vaidya and Manandhar, 1985, p. 133).

The Rana prime ministers possessed the power to take away or confer caste-status on people. When someone was punished for a crime, their caste-status was stripped. But if the Rana rulers were pleased, they could elevate someone from a pani-nachalne caste - that rendered water impure by their touch - into a caste that could touch water that was shared with the 'upper-castes'. In the 1880s, Prime minister Bir Shamsher elevated a woman from the Kau caste - a group whose touch rendered water impure to a higher status because she was his consort (Gautam,1993, p. 115).

I recount these details because although the Muluki-ain of 1854 has been replaced, twice, the social structure strengthened by that set of laws still persists. My mother, who chose to marry the man she loved two years after the caste system was outlawed in 1963, was forced to forfeit everything that was familiar to her. Even decades later, Ajit Mijar Dhakal lost his life for marrying the woman he loved.

My family home was a laboratory for this inhumane, inflexible social system. The list of places where we couldn't go to was longer than that of places where we could go. There were more things we couldn't touch than we could touch; more acts forbidden than permitted; more which couldn't be imagined than could be; more things we couldn't choose for ourselves than we could.

As I voiced my opposition to these prohibitions, people started calling me a sharptongued girl because I spoke my mind. My family and society wanted a girl who was quiet, did not ask questions, obeyed, didn't talk too much, didn't laugh, minded her legs while she sat, and kept away from boys - these were the attributes of a 'good girl'. If a woman spoke out, she was called a loud-mouth. My family faced a desperate time trying to save its daughters from being seen as a troublemaker.

Generally, daughters in Dalit families have to go outside their home for work but we were exceptions. My brothers didn't like it if their teenage sisters went outside. My sister and I were like soldiers on a parade ground, obeying our older brothers' orders. If they said turn left, we turned left. If they said turn right, we turned right. As 
soon as they arrived at home, we would run like crazy to get inside through the back door with our legs still soiled from playing. Sometimes, in a rush, we even used to hold our books upside down. Whenever one of our brothers saw my sister, or me he would command - 'Go, study!'

I was more scared of my brothers than of the graveyard near our home. I got sick of life like a prisoner. But slowly I realized that education is a powerful weapon to escape from darkness. Our brothers wove a strong cordon of love that imprisoned us inside our home. However, their love was suffocating; as if they were holding my head under the waters of the Rapti. It took a long time for me to understand why.

Then we started hearing from villagers that my sister had been sold off. Villagers used to tell me, 'Saru, tero Kiran didi bechiyeko thaha cha talai?' Do you know your sister Kiran has been sold? I could not make sense of this - was my sister like biscuits, for sale? How can a human being be sold? Whenever I asked my bothers and father about Kiran didi, they would make angry faces. My sister's disappearance became a mystery. I learned later that she had been taken to India. Later, I learned, she was not only sold but also raped. Sadly, many similar cases continue to occur, especially involving Dalits and other marginalized communities in Nepal.

The trauma of that incident made my brothers bring us up under strict military discipline. If we sat inside the house, the chances of us falling into trouble decreased. My brothers insisted that we study hard, believing that an educated sister would be safe. To gain education was to rescue oneself. Accompanying their need to protect our bodies and virtue was their preoccupation with protecting the family honor. If the bodies of the wives and daughters of a household are not secured, the prestige and honor of its men are imperiled. In order to protect their honor, every morning I was told to worship God, not to play with other children, not to go afar to herd the cows and goats. In my teens, I loved swimming in the Rapti, fishing, lying on my stomach on a sun-soaked rock after swimming, running after fishermen to collect small leftover fish, herding cows and goats, stealing grass for the cattle, and collecting dry foliage and firewood. All these activities were curtailed to protect the family honor.

The men of my family were also trapped by caste. Even though my sister's rapist walked free in the village, there was nothing we could do because he was high-caste. What else could a calf do except run away from the cheetah? We were the only Dalit family in the neighborhood. And our family worried about ijjat (honor). I can still recall my family bemoaning more about ijjat rather than my sister. Walking out in daylight was a kind of nightmare. I still remember, I used to get scared even of the rapist's shadow. To me, he seemed like a warlock, an old man wearing traditional daura suruwal (loose shirt and trousers) clothes with a Dhaka topi (cap), holding a stick. He had big red eyes and a hooked nose. His teeth looked like a crumbling Stonehenge. I saw him herding cows, bulls, and goats. He walked like a leopard searching for prey. My heart would burn. The fire is still burning. I grew up in anguish, with a sense of helplessness.

We were young girls growing up - we, too, could have become victims of the tendency to withdraw. But in the course of securing and rescuing myself, I learned how not to silence myself for the sake of ijjat (honor) or to make my family happy. Rather, I stood up for truth. Since then, my job has become not to make people happy but to ask them uncomfortable questions; to stand up against unfairness within and outside the family. 
I have shared the history we carry, and the tragic story of Ajit Mijar Dhakal - to illustrate how caste pollutes and dehumanizes the Nepali society. Nepal has recently become a democratic republic after a long-drawn political and social struggle, including a civil war that killed about seventeen thousand people. It has adopted the principle of proportional inclusiveness. But the drafters of the new constitution have sometimes behaved like the dharmadhikaris of the past. For one thing, they attempted, absurdly, to limit the definition of secularism to mean the continuation of Sanatan traditions and domination of Hinduism over other faiths. For another, women have been made second-class citizens, denied the right to pass citizenship on to their children. The new dharmadhikaris seem eager to take away even the smallest reservations made to benefit those kept in exclusion for centuries. When Dalits stand up to demand justice, they are put on a slab of ice like Ajit Mijar Dhakal.

Must we, even now, continue to fight for equality in this new republic? Does Ajit Dhakal have to lose his life for the mere fact of falling in love with a so-called highcaste woman? Can there be a more cruel democracy than this? Let the examination of how caste continues to strip people of their humanity become an issue for intellectual discourse not just in Nepal and South Asia but in every international democratic forum.

\section{References}

Chakravarti, Uma. (2003). Gendering Caste Through a Feminist Lens. Calcutta, STREE, Bhatkal and Sen.

Gautam, Rajesh. (1993, V.S 2050). Ranakalin Nepal Ko Ek Jhalak. Kathmandu, Ratna Pustak Bhandar.

Hofer, Andras. (2012, 1979). The Caste Hierarchy and the State in Nepal, A Study of the Muluki Ain of 1854. Kathmandu, Himal books.

Pariyar, Sarita. (2018). Old Weight of Caste. The Record. Retrieved on October 27, 2020 from https:/www.recordnepal.com/podcast/the-old-weight-of-caste/

Pariyar, Sarita. (2018). Untouchable Stories of Touchable Vaginas. The Record. Retrieved on October 27, 2020 from https://www.recordnepal.com/wire/untouchable-stories-oftouchable-vaginas/

Regmi, Mahesh C. (2002). Nepal An Historical Miscellany. New Delhi, Adroit Publishers.

Vaidya, Tulasi Ram, Tri Ratna Manandhar. (1985). Crime and Punishment in Nepal, Kathmandu, Bini Vaidya and Purna Devi Manandhar.

Asian Human Rights Commission NEPAL: Ajit Mijar's Death - not Suicide, but Murder, July 27, 2016. Retrieved from http://www.humanrights.asia/news/ahrc-news/AHRC-STM-1092016.

During the writing of this paper translation assistance was received from Prawin Adhikari.

\section{Endnotes}

1 The caste groups of the Muluki Ain 1854

2. Tagadhari: Wearers of the holy cord

3. Namasinya matwali: Non-enslavable Alcohol-Drinkers

4. Masinya matwali: Enslavable Alcohol-Drinkers

5. Pani nacalnya chhoi chhito halnu-naparnya: Impure, but touchable castes)

6. Pani nacalnya chhoi chhito halnu-parnya: Impure and untouchable castes (Hofer, 2012 p. 10) 